\title{
Obesity: A Review of Pathogenesis and Management Strategies in Adult
}

\author{
Nazma Aktar ${ }^{1}$, Nazmul Kabir Qureshi ${ }^{2}$, Hossain Shahid Ferdous ${ }^{3}$
}

\begin{abstract}
Obesity is a chronic metabolic disease characterized by an increase of body fat stores. It is a gateway to ill health, and has become one of the leading causes of disability and death, affecting not only adults but also children and adolescents worldwide. Obesity is a major risk factor for cancer, cardiovascular, metabolic, and respiratory disorders. This presents an ever increasing social and economic burden to individuals, families and the healthcare system. Preventing obesity is the optimal long-term population strategy. A comprehensive history, physical examination and laboratory assessment relevant to the patient's obesity should be obtained. Appropriate goals of weight management emphasize realistic weight loss to achieve a reduction in health risks and should include promotion of weight loss, maintenance and prevention of weight regain. Management of co-morbidities and improving quality of life of obese patients are also included in treatment aims.Treatment should be based on good clinical care, and evidence-based interventions; should focus on realistic goals and lifelong multidisciplinary management. A comprehensive obesity management can only be accomplished by a multidisciplinary obesity management team. We conclude that physicians have a responsibility to recognize obesity as a disease and help obese patients with appropriate prevention and treatment. This review addresses the current therapeutic options in the treatment of obesity, focusing on pathogenesis, lifestyle changes, medications, and surgery. It also presents a suggested algorithm for the clinician assessing and managing obese patients.
\end{abstract}

\section{Search strategy:}

We searched journal of obesity, clinical guideline for obesity, Pub Med for reviews and original articles related to obesity management. Keywords used included obesity, pathogenesis, multidisciplinary management, and pharmacotherapy.

Keywords: Obesity; pathogenesis; multidisciplinary management.

Delta Med Col J. Jan 2017;5(1):35 - 48

\section{Introduction}

Obesity is a metabolic disease that has reached epidemic proportions. The World Health Organization (WHO) has declared obesity as the largest global chronic health problem in adults which is increasingly turning into a more serious problem than malnutrition. ${ }^{1}$ In 2014 , more than

1. Resident Physician, Dept. of Medicine, MARKS Medical College \& Hospital, Dhaka, Bangladesh.

2. Specialist, Dept. of Medicine, United Hospital Limited, Dhaka, Bangladesh.

3. Senior Consultant, Dept. of Endocrinology, BIRDEM General Hospital \& Ibrahim Medical College, Dhaka, Bangladesh.

Correspondence: Dr. Nazma Aktar. e-mail: nazma_aktar_endo@yahoo.com 
1.9 billion adults (18 years and older) were overweight. Of these over 600 million were obese. 42 million children under the age of 5 were overweight or obese in $2013 .^{2}$ It has been further projected that $60 \%$ of the world's population, i.e. 3.3 billion people, could be overweight (2.2 billion) or obese (1.1 billion) by 2030 if recent trends continue. ${ }^{3}$ In 2010, overweight and obesity were estimated to cause 3.4 million deaths, $4 \%$ of years of life lost, and $4 \%$ of disability-adjusted life years (DALYs). ${ }^{4}$ Obesity is a risk factor for several of the leading causes of preventable death, including cardiovascular disease, diabetes mellitus, and many types of cancer. Thus, successful treatment and control of obesity should be major imperatives. However, multiple studies have shown that detection and counseling rates among physicians remain low. ${ }^{5-8}$ Thus, a gap exists between the need to provide obesity care and the actual provision of care. In this article, current recommendations for the medical evaluation of the obese adult patient are reviewed, followed by management approaches to using lifestyle therapy, pharmacotherapy, and surgery.

\section{Definition and classification}

In clinical practice, the body fatness is usually estimated by BMI. BMI is calculated as measured body weight $(\mathrm{kg})$ divided by measured height squared $\left(\mathrm{m}^{2}\right)$. Patients with a BMI of $25 \mathrm{~kg} / \mathrm{m}^{2}$ or greater are classified as being overweight. Pre obesity and obesity class I, II and III (extreme obesity) are defined as a BMI of $25 \mathrm{~kg} / \mathrm{m}^{2}$ to 29.9 $\mathrm{kg} / \mathrm{m}^{2}, 30 \mathrm{~kg} / \mathrm{m}^{2}$ to $34.9 \mathrm{~kg} / \mathrm{m}^{2}, 35 \mathrm{~kg} / \mathrm{m}^{2}$ to 39.9 $\mathrm{kg} / \mathrm{m}^{2}$, and $40 \mathrm{~kg} / \mathrm{m}^{2}$ or greater, respectively. (Table I)

\section{Table I: BMI categories ${ }^{9}$}

\begin{tabular}{lc}
\hline Category & BMI $\left(\mathbf{k g} / \mathbf{m}^{\mathbf{2}}\right)$ \\
\hline Underweight & $<18.5$ \\
Healthy weight & $18.5-24.9$ \\
Pre-obese state & $25.0-29.9$ \\
Obesity grade I & $30.0-34.9$ \\
Obesity grade II & $35.0-39.9$ \\
Obesity grade III & $\geq 40$ \\
\hline
\end{tabular}

However, obesity-related disease risk is also increased in individuals with normal weight and BMI who have an increased waist circumference (WC): a waist circumference of more than $102 \mathrm{~cm}$ (40 inches) in men and more than $88 \mathrm{~cm}$ (35 inches) in women. ${ }^{10}$ Waist circumference is an indirect measurement of visceral adiposity, which is metabolically active and responsible for the secretion of pro-inflammatory cytokines that are, in part, responsible for the pathogenesis of insulin resistance and the metabolic syndrome. Accumulation of intra-abdominal fat is associated with higher metabolic and cardiovascular disease risk. ${ }^{11,12}$ The amount of abdominal fat can be assessed by waist circumference which highly correlates with intra-abdominal fat content. The WC is measured in the horizontal plane midway in the distance of the superior iliac crest and the lower margin of the last rib. ${ }^{13}$

\section{Pathogenesis and etiology}

The etiology of obesity is multifactorial, involving a complex interaction among genetics, hormones and the environment. Though multiple candidate genes have been implicated in the pathogenesis of obesity, these findings are inconsistent. ${ }^{14,15}$ These genes include the beta-3-adrenergic receptor gene, peroxisome-proliferator-activated receptor gamma 2 genes, chromosome 10p, melanocortin-4 receptor gene and other genetic polymorphisms. ${ }^{14}$

Multiple hormones are involved in the regulation and pathophysiology of obesity, including gut-related hormones, adipokines and others. Ghrelin is a circulating peptide hormone derived from the stomach. It is the only known peripherally acting orexigenic hormone and is responsible for stimulating appetite. ${ }^{16}$ All other gut-derived hormones serve as anorectic agents that are responsible for limiting food intake to achieve optimal digestion and absorption while avoiding the consequences of overfeeding, such as hyperinsulinemia and insulin resistance. These 
anorectic gut hormones are Peptide YY (PYY) ${ }^{17}$, Cholecystokinin (CCK)18, Glucagon-like peptide $-1,{ }^{19}$, etc.

Several hormones, collectively referred to as adipokines, are produced by the adipocytes. The key secretory products are tumour necrosis factor-alpha (TNF- $\alpha$ ), interleukin-6 (IL-6), leptin and adiponectin. The role of TNF- $\alpha$ in obesity has been linked to insulin resistance through the liberation of free fatty acids, reduction in adiponectin synthesis and impairment of insulin signaling. Leptin acts as a dominant long-term signal responsible for informing the brain of adipose energy reserves. Leptin is transported across the blood-brain barrier and binds to specific receptors on appetite-modulating neurons and the arcuate nucleus in the hypothalamus, inhibiting appetite. ${ }^{20}$ Adiponectin is an adipokine derived from plasma protein. It is insulin sensitizing, anti-inflammatory and antiatherogenic and adiponectin levels are restored to normal levels after weight loss. ${ }^{21,22}$

Secondary causes of obesity include drugs, and neuroendocrine diseases (hypothalamic, pituitary, thyroid and adrenal). ${ }^{22}$ High energy density diet, increased portion size, low physical activity and adoption of a sedentary lifestyle as well as eating disorders are considered as important risk factors for the development of obesity. ${ }^{23,24}$ These behavioral and environmental factors lead to alterations in adipose tissue structure (hypertrophy and hyperplasia of adipocytes, inflammation) and secretion (e.g. adipokines). ${ }^{25,} 26$

\section{Clinical evaluation of the obese patient}

A comprehensive history, physical examination and laboratory assessment relevant to the patient's obesity should be obtained. ${ }^{27-29}$

\section{Taking an obesity-focused history}

The first step in initiating obesity care is to take a comprehensive history that addresses issues and concerns specific to obesity treatment. This obesity-focused history allows the physician to develop tailored treatment recommendations that are more consistent with the needs and goals of the individual patient. ${ }^{30}$ For many patients, weight gain initially occurs with or is accelerated coincident to smoking cessation, initiation of a medication, or change in life events such as a change in marital status, change in occupation, or illness. ${ }^{30}$ At-risk times for women include pregnancy and menopause. Stressful life events often result in a change in eating and physical activity habits. Insight into predisposing genetic factors is obtained by taking a family history. ${ }^{31}$

Similarly, it is important to ascertain whether the patient was overweight as a child or adolescent because early onset of obesity is a predictor of severe obesity in adulthood. ${ }^{32}$ A dietary and physical activity history should be assessed in all patients before counseling is initiated. Assessment of psychological health and psychiatric history should be done routinely during the history. ${ }^{33}$ Probing for conditions of disordered eating such as binge eating disorder, bulimia, or night-eating syndrome or other psychological conditions that may impair treatment such as attention deficit disorder or post traumatic stress disorder should be part of a comprehensive obesity history. ${ }^{34}$

\section{Physical examination of the obese patient}

According to the World Health Organization, assessment of risk status resulting from overweight or obesity is based on the patient's BMI, waist circumference, and existence of comorbid conditions. , $^{9,35}$

Presence and impact of obesity-related diseases (diabetes, hypertension, dyslipidaemia, cardiovascular, respiratory and joint diseases; non-alcoholic fatty liver disease (NAFLD), sleep disorders, etc should be assessed.

Presence of acanthosis nigricans as a sign of insulin resistance should be looked for.

\section{Laboratory examinations}

The minimum data set required will include fasting blood glucose, serum lipid profile (total, HDL and LDL cholesterol, triglycerides), uric 
acid, thyroid function (thyroid-stimulating hormone [TSH] level), liver function (hepatic enzymes), liver investigation (ultrasound, biopsy) if abnormal liver function tests suggest NAFLD or other liver pathology, cardiovascular assessment, if indicated, endocrine evaluation if Cushing's syndrome or hypothalamic disease suspected and sleep laboratory investigation for sleep apnoea. ${ }^{27-29}$

\section{Comprehensive obesity management}

Appropriate goals of weight management emphasize realistic weight loss to achieve a reduction in health risks and should include promotion of weight loss, maintenance and prevention of weight regain. Weight loss occurs by generating a negative energy balance, which is achieved by consuming fewer calories than energy expended. A physician should discuss with the patient before deciding the initial level of intervention. (Table II)

Table II: A guide to deciding the initial level of intervention to discuss with the patient ${ }^{36}$

\begin{tabular}{llll}
\hline BMI, $\mathbf{~ k g} / \mathbf{m}^{2 *}$ & WC, $\mathbf{c m}^{*}$ & men $\geq 94$, & Co-morbidities \\
\hline & men $<94$, & women $\geq 80$ & \\
& women $<80$ & & \\
$25.0-29.9$ & $\mathrm{~L}$ & $\mathrm{~L}$ & $\mathrm{~L} \pm \mathrm{D}$ \\
$30.0-34.9$ & $\mathrm{~L}$ & $\mathrm{~L} \pm \mathrm{D}$ & $\mathrm{L} \pm \mathrm{D} \pm \mathrm{S}^{* *}$ \\
$35.0-39.9$ & $\mathrm{~L} \pm \mathrm{D}$ & $\mathrm{L} \pm \mathrm{D}$ & $\mathrm{L} \pm \mathrm{D} \pm \mathrm{S}$ \\
$\geq 40.0$ & $\mathrm{~L} \pm \mathrm{D} \pm \mathrm{S}$ & $\mathrm{L} \pm \mathrm{D} \pm \mathrm{S}$ & $\mathrm{L} \pm \mathrm{D} \pm \mathrm{S}$ \\
\hline
\end{tabular}

$\mathrm{L}=$ Lifestyle intervention (diet and physical activity); $\mathrm{D}=$ consider drugs; $\mathrm{S}=$ consider surgery. *BMI and waist circumference cut-off points are different for some ethnic groups. **Patients with type 2 diabetes on individual basis.

The evidence and recommendations for nonpharmacological management of obesity, including diet therapy, physical activity and behavioural therapy, as well as pharmacotherapy, and bariatric surgery are discussed in the present review.

\section{Lifestyle treatment}

The foundation of obesity care is assisting the patient in making healthier dietary and physical activity choices that will lead to a net negative energy balance. The initial goal is to achieve a $5 \%$ to $10 \%$ weight loss over the initial 6 months of treatment. ${ }^{37}$ A comprehensive review of lifestyle modification for obesity was previously provided by Wadden et al. ${ }^{38}$ It is important to remember that personal choices are heavily influenced by exposure to environmental factors, i.e., home and work life, access, affordability, media, and advertising, so all recommendations must have a contextual perspective. ${ }^{39}$ Caloric reductions is the most important component in achieving weight loss, whereas increased and sustained physical activity is particularly important in maintaining the lost weight. ${ }^{40-44}$

\section{Diet therapy}

Weight loss is dependent primarily on reducing total caloric intake, not the proportions of carbohydrate, fat, and protein in the diet. ${ }^{43}$ The macronutrient composition (i.e., proportion of calories from carbohydrate, fat, and protein) will ultimately be determined by the patient's taste preferences, cooking style, and culture. However, the patient's underlying medical problems are also important in guiding the recommended dietary composition. A consultation with a registered dietitian for medical nutrition therapy is particularly useful, ${ }^{45}$ along with the importance of emphasizing collaborative care and self-management of chronic disease. ${ }^{46}$ Incorporating meal replacements into the diet is another useful strategy. Meal replacements are foods designed to take the place of a meal or snack while providing nutrients and good taste within a fixed caloric limit. ${ }^{47,48}$ Dietary advice should encourage healthy eating and emphasize the need to increase consumption of vegetables, beans, legumes, lentils, grain, unsweetened cereals and fiber, and to substitute low-fat dairy products and meats for high-fat alternatives. It should also emphasize increased intake of seafood. It is recommended to avoid foods containing added sugars and solid fats, as well as consumption of 
sugary drinks and alcohol-containing beverages. ${ }^{49-52}$

\section{General advice}

- Decrease energy density of foods and drinks

- Decrease the size of food portions

- Avoid snacking between meals

- Do not skip breakfast and avoid eating in the night time

- Manage and reduce episodes of loss of control or binge eating.

\section{Physical Activity}

Obesity is related to a sedentary lifestyle. Exercise causes lipolysis, resulting in free fatty acid release from triglycerides stored in fat for use as an energy source by muscle, increasing energy expenditure. ${ }^{53}$ Although some reports indicate that exercise alone can produce a $2 \%$ to $3 \%$ reduction in BMI, it is a more effective weight loss tool when used in conjunction with dietary modification. The majority of the literature suggests that physical activity alone is ineffective in achieving initial weight loss or results in only modest weight loss of a few kilograms. ${ }^{54}$ However, physical activity can help in long-term weight loss maintenance. ${ }^{55}$

A starting program of $30 \mathrm{~min}$ to $45 \mathrm{~min}$ of moderate exercise (e.g., brisk walking) at least three days per week is recommended. This amount of physical activity expends approximately 150 kcal/day (500 to 1000 calories per week). For some, this may not be adequate energy expenditure and these individuals may require a loss of 2000 calories or more per week to ensure weight loss maintenance. Any form of physical activity is appropriate as long as it increases heart rate and energy expenditure. Walking is the most common, safe and accessible mode of exercise that is prescribed. The National Weight Control Registry recommends that individuals initially walk 4000 steps per day, with a gradual increase to 12,000 steps per day over a period of six months. ${ }^{53}$

\section{Behavioral modification}

Behavioral strategies are designed to change patients' dietary and exercise habits. They target obstacles that limit adherence to diets. These strategies include self-monitoring of eating habits and physical activity, stress management of situations that lead to overeating, avoiding situations that lead to incidental eating, cognitive restructuring to correct unrealistic goals and misconceptions about weight loss and body image, social support from family and friends, and relapse prevention after episodes of overeating or weight gain. Individuals who receive regular behavioral therapy such as regular contact with treatment providers are more likely to achieve and maintain long-term weight loss. ${ }^{53}$

\section{Treatment}

\section{Aims of treatment}

The management and treatment of obesity (Fig. 1) have wider objectives than weight loss alone and include risk reduction and health improvement. Significant clinical benefits may be achieved even by modest weight loss (i.e., $5-10 \%$ of initial body weight), and lifestyle modification. ${ }^{56-59}$ More attention is to be paid to $\mathrm{WC}$ and the improvement in body composition which is focusing on ameliorating or maintaining free fat mass (FFM) and decreasing fat mass. ${ }^{60}$ Management of co-morbidities, improving quality of life and well-being of obese patients are also included in treatment aims. Obesity management may reduce the need to treat co-morbidities by drugs. ${ }^{49,61,62}$ Referral to an obesity specialist (or an obesity management team) should be considered if the patient fails to lose weight in response to the prescribed intervention ( Fig. 1). Weight cycling, defined by repeated loss and regain of body weight, is more frequent in women and may be linked to increased risk for hypertension, dyslipidaemia and gallbladder disease. ${ }^{63}$ Obesity is a chronic disease. A follow-up and continued supervision is necessary to prevent weight regain, and to monitor disease risks. 64 


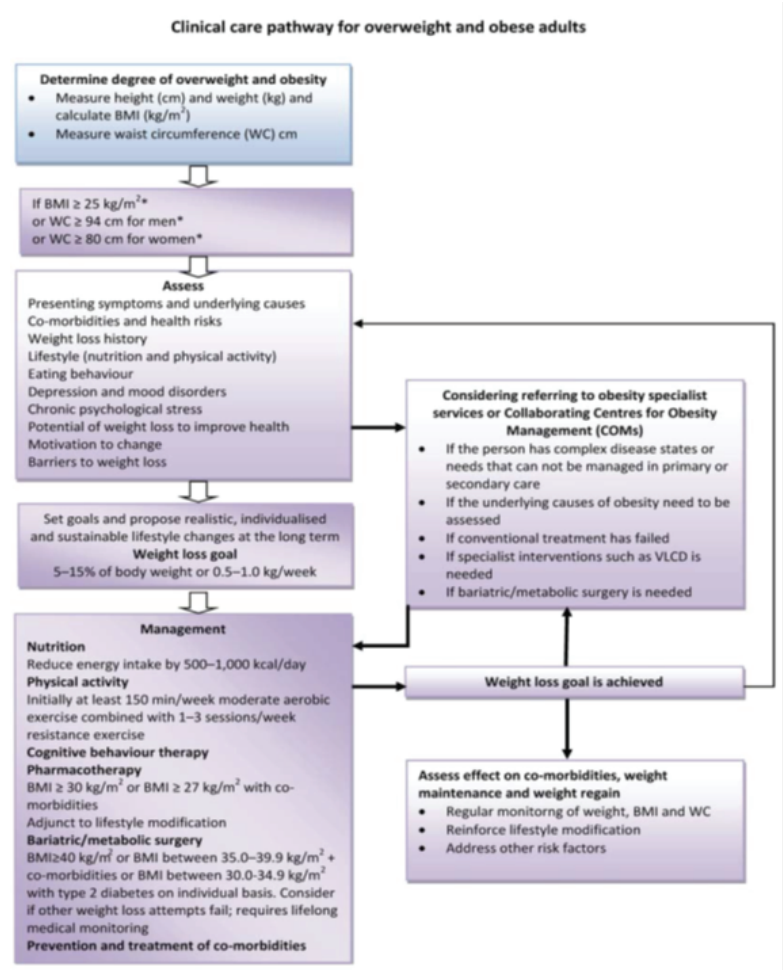

Fig. 2: Algorithm for the assessment and stepwise management of overweight andobese adults

*BMI and WC cut-off points are different for some ethnic groups. ${ }^{36}$

\section{Pharmacotherapy}

Antiobesity drug therapy is indicated for those individuals who cannot achieve weight loss despite an adequate trial of lifestyle modification. Pharmacotherapy should only be prescribed in conjunction with lifestyle modifications, and not as monotherapy for obesity. According to current Food and Drug Administration (FDA) guidance, pharmacotherapy is approved for patients with a BMI $\geq 30 \mathrm{~kg} / \mathrm{m}^{2}$ or $\geq 27 \mathrm{~kg} / \mathrm{m}^{2}$ when complicated by obesity comorbidity 49 (Table II). Although sound in principle, few agents are currently approved for treatment of obesity. They fall into 2 major categories: appetite suppressants or anorexiants and gastrointestinal fat blockers. ${ }^{65-67}$ Regardless of whether new antiobesity agents are available, it is important to avoid or minimize weight-gaining medications when possible. ${ }^{68}$ Although there are a wide variety of weight loss agents that have been tested in the treatment of obesity, currently only sibutramine and orlistat are approved worldwide. 69 Drugs should be used according to their licensed indications and restrictions. The efficacy of pharmacotherapy should be evaluated after the first 3 months. If weight loss achieved is satisfactory ( $>5 \%$ weight loss in non-diabetic and $>3 \%$ in diabetic patients), treatment should be continued. ${ }^{49,70-73}$ Treatment should be discontinued in non-responders.

\section{Orlistat}

Orlistat is a potent, irreversible inhibitor of gastric and pancreatic lipases that reduce systemic absorption of dietary fat by $30 \%$. Randomized clinical trials reveal a $3 \mathrm{~kg}$ weight loss or $3 \%$ greater reduction in weight than with the ingestion of a placebo. It also reduced low density lipoprotein and cholesterol levels independently of body weight reduction, delayed diabetes, improved glycemic control in diabetic patients and significantly reduced systolic and diastolic blood pressure. Orlistat has been evaluated in weight loss maintenance. At one year, patients treated with $120 \mathrm{mg}$ of orlistat, three times per day had significantly less weight regain than those in the placebo group. ${ }^{74}$ Side effects include liquid stools, steatorrhea, fecal urgency, incontinence, flatulence, abdominal cramping and fat-soluble vitamin deficiencies.

\section{Sibutramine}

Sibutramine was initially developed as an anti-depressant and was incidentally found to reduce body weight, decrease appetite and increase satiety. It inhibits norepinephrine and serotonin reuptake without stimulating their release. ${ }^{69}$ Three trials lasting at least one year demonstrated a weight loss of $4 \mathrm{~kg}$ or $5 \%$ more than placebo; $35 \%$ more patients achieved at least $5 \%$ weight loss and $15 \%$ more patients achieved at least $10 \%$ weight loss compared to patients ingesting the placebo. Patients who received 10 $\mathrm{mg}$ /day or $15 \mathrm{mg}$ /day of sibutramine experienced a greater weight loss than those who received the 
placebo with dietary advice over a one-year period, with a weight reduction of $4.4 \mathrm{~kg}, 6.4 \mathrm{~kg}$ and $1.6 \mathrm{~kg}(\mathrm{p} \leq 0.01)$, respectively. ${ }^{75}$ Sibutramine has also been shown to be effective at weight loss maintenance. ${ }^{76}$ The main side effects of sibutramine are tachycardia and increase in blood pressure, nervousness and insomnia. Some patients may also complain of dry mouth and constipation. The drug is contraindicated in patients using monoamine oxidase inhibitors and selective serotonin reuptake inhibitors.

\section{Lorcaserin}

Lorcaserin is a serotonin type $2 \mathrm{C}$ receptor agonist with hypophagic effects. ${ }^{77}$ Lorcaserin has been available in the USA since June 2013. The recommended dose is $10 \mathrm{mg}$ twice daily. The product license requires 5\% weight loss after 12 weeks of treatment. If a patient does not reach this target, the drug should be discontinued. . $0-73,78,79^{-1}$ The efficacy and safety of the drug were assessed in the following RCTs: BLOOM 65 , BLOOM-DM $^{80}$ and BLOSSOM ${ }^{81}$. In the BLOOM-DM trial, both fasting blood glucose and haemoglobin A1C (HbA1c) levels were improved. ${ }^{80,82}$ The most common adverse events associated with lorcaserin included blurred vision, dizziness, somnolence, headache, gastrointestinal disturbance and nausea.

\section{Phentermine/Topiramate}

Phentermine and extended-release topiramate is based on the principle of a synergistic combination of two drugs at a lower dose to obtain efficacy with less toxicity. Phentermine is an atypical amphetamine analogue that suppresses appetite by norepinephrine agonism in the CNS. Topiramate is an atypical anticonvulsant drug previously evaluated as a potential anti-obesity drug after reports of weight loss occurring in epileptic patients taking this drug. The mechanisms by which topiramate induces a weight loss are unknown and may include carbonic anhydrase inhibition of taste or influences on GABA transmission, thus reducing appetite. ${ }^{83}$ After approval by the FDA, the drug was launched in the USA in September 2012. The recommended dosage is $7.5 \mathrm{mg}$ phentermine / $46 \mathrm{mg}$ topiramate once a day. The product license requires 5\% weight loss after 12 weeks of treatment. If a patient does not reach this target, the drug should be discontinued..$^{70-73}$ The efficacy and safety of the drug were assessed in the following RCTs: EQUIP $^{84}, \quad$ CONQUER $^{67}, \quad$ SEQUEL $^{85}$ and EQUATE ${ }^{86}$. Adverse events associated with treatment were dry mouth, constipation, insomnia, palpitations, dizziness, paraesthesia, disturbances in attention, metabolic acidosis and renal calculi, headache, dysgeusia (distortion of sense of taste), alopecia and hypokalaemia. ${ }^{70-73,87}$ The combination is contraindicated during pregnancy due to its teratogenic potential. Owing to this risk, the drug has been approved with a risk evaluation and mitigation strategy recommendation by the FDA. ${ }^{88}$

\section{Bupropion/Naltrexone}

Bupropion/naltrexone combines two centrally acting medications that had already been approved. Bupropion is used for treating depression and to aid smoking cessation. It is a nonselective inhibitor of the dopamine and norepinephrine transporters. Naltrexone is an opioid receptor antagonist widely used to treat alcohol and opiate dependence syndromes. The anorectic effect of the bupropion/naltrexone combination is believed to result from activation of POMC neurons in the arcuate nucleus. POMC neurons release a melanocyte stimulating hormone $(\alpha-\mathrm{MSH})$, which is a potent anorectic feeding neuropeptide, and these neurons project to other hypothalamic areas involved in feeding and body weight control. After approval by the FDA and the European Medicinal Agency (EMA), the drug is available in the USA since September 2012 and will be launched in Europe in approximately mid 2016. There commended dosage is $16 \mathrm{mg}$ naltrexone / $180 \mathrm{mg}$ bupropion twice a day. The product license requires 5\% weight loss after 12 
weeks of treatment. If a patient does not reach this target, the drug should be discontinued. ${ }^{70-73,89}$ The efficacy and safety of the drug were assessed in the following RCTs: COR-I ${ }^{66}$, COR-II ${ }^{90}$, COR-BMOD $^{91}$ and COR-DM ${ }^{92}$. Nausea, headache, dizziness, insomnia and vomiting were the most common adverse events that led to discontinuation. ${ }^{89}$

\section{Liraglutide}

Liraglutide is an injectable long-acting GLP-1R agonist designed to resist rapid metabolism by dipeptidyl peptidase-IV. While glucose-induced insulin release is stimulated, the glucagon response is reduced and appetite suppressed with additional effects on gastric emptying. ${ }^{92}$ It has already successfully been introduced in type 2 diabetic patients (1.2-1.8 mg) once daily. After approval by the FDA and EMA, the drug (in a dosage of $3 \mathrm{mg}$ once daily) was launched for obesity treatment in the USA in November 2014 and in Europe in March 2015. The product license requires $5 \%$ weight loss after 12 weeks of treatment. If a patient does not reach this target, the drug should be discontinued. ${ }^{70-73,93-97}$ The efficacy and safety of the drug were assessed in the following RCTs: SCALE-Maintenance ${ }^{98}$, SCALE-Obesity 99 and LEADER ${ }^{100-102 .}$ Liraglutide is generally well tolerated. Nausea and vomiting are the transient side-effects, but they may actively contribute to weight loss. ${ }^{103}$

\section{Bariatric and metabolic surgery}

According to the $1991 \mathrm{NIH}$ Consensus Development Conference Panel on bariatric surgery, ${ }^{104}$ patients with a BMI $\geq 40 \mathrm{~kg} / \mathrm{m}^{2}$ or those with a BMI $\geq 35 \mathrm{~kg} / \mathrm{m}^{2}$ who have associated high-risk co-morbid conditions such as cardiopulmonary disease or type 2 diabetes mellitus could be considered surgical candidates. Surgical weight loss can be achieved by restrictive, malabsorptive or combination procedures.

Roux-en-Y gastric bypass surgery results in weight loss by gastric restriction, causing early satiety and malabsorption, as well as reduction in hunger due to a decrease in ghrelin levels and increased PYY. The approximate weight loss at one year is $50 \% .{ }^{105}$ Complications associated with this surgery include deficiencies in iron, calcium, vitamin B12, fat-soluble vitamins, folic acid and electrolytes.

Vertical banded gastroplasty is a purely restrictive procedure by which the patient is left with a pouch that dilates to only $250 \mathrm{~mm}$ in diameter. Vomiting is a common side effect. Weight loss with compliance is $60 \%$. ${ }^{106}$ Drawbacks of the procedure are that high calorie beverage ingestion can eventually lead to weight gain. Furthermore, the pouch can expand with overeating.

Laparoscopic adjustable gastric banding, another purely restrictive procedure, involves placing a small silicone band around the fundus of the stomach. It is a short day-surgery and can be adjusted after placement. Weight loss seen after this procedure is also approximately $60 \% .106$ Contraindications include an extremely high operative risk, active substance abuse, or a major unstable or uncontrolled psychopathological condition such as major depressive disorder, schizophrenia, or bulimia. All patients who are considering weight loss surgery should undergo a comprehensive assessment by a multidisciplinary team of healthcare providers that includes a physician, registered dietitian, and mental health professional. ${ }^{107}$

\section{Treatment of co-morbidities}

Active treatment of obesity-related co-morbidities should be integral part of the comprehensive management of the obese patients. Appropriate management of obesity complications in addition to weight management should include:49,108

- Management of dyslipidaemia

- Optimising glycaemic control in type 2 diabetics

- Normalising blood pressure in hypertension

- Management of pulmonary disorders

- Attention to pain control and mobility needs in osteoarthritis 
- Management of psychosocial disturbances, including affective disorders, eating disorders, low self-esteem and body image disturbance.

The presence of obesity and the effects that treatments have on body weight, body composition or metabolic status should be taken into account in the selection of the drugs used to treat obesity-related co-morbidities or even non-obesity-related diseases occurring in a patient with obesity. ${ }^{72}$

\section{Conclusions}

Obesity is a serious and highly prevalent disease associated with increased morbidity and mortality. A thorough medical assessment is required to identify patients who are obese or at risk for obesity or obesity-related complications. Treatment should be based on good clinical care and evidence-based interventions and it should be individualized and multidisciplinary, focus on realistic goals, weight maintenance and prevention of weight regain. All patients should be provided lifestyle therapy with consideration for pharmacotherapy and bariatric surgery when indicated. Physicians have a responsibility to recognize obesity as a gateway to disease and help patients with appropriate prevention and treatment schemes for obesity and its co-morbidities.

\section{References}

1. Frühbeck G, Toplak H, Woodward E, Yumuk V, Maislos M, Oppert JM; Executive Committee of the European Association for the Study of Obesity. Obesity: the Gateway to Ill Health - an EASO Position Statement on a Rising Public Health, Clinical and Scientific Challenge in Europe. Obes Facts. 2013;6:117-20

2. World Health Organization: Obesity and Overweight. WHO Fact Sheet No. 311, Geneva: WHO; 2015

3. Kelly T, Yang W, Chen CS, Reynolds K, He J. Global Burden of Obesity in 2005 and Projections to 2030. Int J Obes (Lond). 2008;32:1431-37.
4. Ng M, Fleming T, Robinson M, Thomson B, Graetz N. A Systematic Analysis for the Global Burden of Disease Study 2013. Lancet 2014;384:766-81.

5. Jackson JE, Doescher MP, Saver BG, Hart LG. Trends in Professional Advice to Lose Weight among Obese Adults, 1994-2000. J Gen Intern Med. 2005;20:814-18.

6. McAlpine DD, Wilson AR. Trends in Obesity-Related Counseling in Primary Care: 1995-2004. Med Care. 2007;45:322-29.

7. Kushner RF. Tackling obesity: is Primary Care up to the Challenge? Arch Intern Med. 2010;170:121-23.

8. Haire-Joshu D, Klein S. Is Primary Care Practice Equipped to Deal with Obesity? Arch Intern Med. 2011;171:313-15.

9. Obesity: Preventing and Managing the Global Epidemic. Geneva, Switzerland: World Health Organization; 1998.

10. National Heart, Lung and Blood Institute, North American Association for the Study of Obesity. Practical Guide to the Identification, Evaluation, and Treatment of Overweight and Obesity in Adults. National Institute of Health; 2000.

11. Obesity: Preventing and Managing the Global Epidemic. Report of a WHO Consultation. Geneva: WHO Technical Report Series 894; 2000.

12. Zhu S, Wang Z, Heshka S, Heo M, Faith MS, Heymsfield SB. Waist Circumference and Obesity Associated Risk Factors among Whites in the Third National Health and Nutrition Examination Survey: Clinical Action Thresholds. Am J Clin Nutr. 2002;76:743-49.

13. Alberti KG, Zimmet PZ, Shaw J. The Metabolic Syndrome - a New Worldwide Definition. Lancet. 2005;366:1059-62.

14. Clement K, Vaisse C, Manning BS, Basdevant A, Guy-Grand B, Ruiz J, et al. Genetic Variation in the Beta 3-Adrenergic Receptor and an Increased Capacity to Gain Weight in Patients with Morbid Obesity. N Engl J Med. 1995;333:352-54.

15 Ristow M, Muller-Wieland D, Pfeiffer A, Krone W, Kahn CR. Obesity Associated with a Mutation in a Genetic Regulator of Adipocyte Differentiation. N Engl J Med. 1998;339:953-59. 
16. Tschop M, Weyer C, Tataranni PA, Devanarayan V, Ravussin E, Heiman ML. Circulating Ghrelin Levels Are Decreased in Human Obesity. Diabetes. 2001;50:707-709.

17. Degen L, Oesch S, Casanova M, Graf S, Ketterer S, Drewe J, et al. Effect of Peptide YY3-36 on Food Intake in Humans. Gastroenterology. 2005;129:1430-36.

18. Cohen MA, Ellis SM, Le Roux CW, Batterham RL, Park A, Patterson M, et al. Oxyntomodulin Suppresses Appetite and Reduces Food Intake in Humans. J Clin Endocrinol Metab. 2003;88:4696-701.

19. Flint A, Raben A, Astrup A, Holst JJ. Glucagon-like Peptide 1 Promotes Satiety and Suppresses Energy Intake in Humans. J Clin Invest. 1998;101:515-20 .

20. Mizuno TM, Kelley KA, Pasinetti GM, Roberts JL, Mobbs CV. Transgenic Neuronal Expression of Proopiomelanocortin Attenuates Hyperphagic Response to Fasting and Reverses Metabolic Impairments in Leptin-Deficient Obese Mice. Diabetes. 2003;52:2675-83.

21. Matsuzawa Y, Funahashi T, Kihara S, Shimomura I. Adiponectin and Metabolic Syndrome. Arterioscler Thromb Vasc Biol. 2004;24:29-33.

22. Oh DK, Ciaraldi T, Henry RR. Adiponectin in Health and Disease. Diabetes Obes Metab. 2007;9:282-89.

23. James WP. The Epidemiology of Obesity: The Size of the Problem. J Intern Med. 2008;263:336-52.

24. Branca F, Nikogosian H, Lobstein T, editors. The Challenge of Obesity in the WHO European Region and the Strategies for Response: Summary. Copenhagen: WHO Regional Office for Europe; 2007.

25. Ailhaud G. Adipose Tissue as a Secretory Organ: from Adipogenesis to the Metabolic Syndrome. C R Biol. 2006;329:570-77.

26. Tilg H, Moschen AR. Adipocytokines: Mediators Linking Adipose Tissue, Inflammation and Immunity. Nat Rev Immunol. 2006;6:772-83.

27. National Institutes of Health: The Practical Guide: Identification, Evaluation, and Treatment of Overweight and Obesity in Adults. NHLBI Obesity Education Initiative Expert Panel on the
Identification, Evaluation, and Treatment of Overweight and Obesity in Adults. Bethesda, NIH. 2000 (cited 2015 Nov 30). Available from: http:/www.nhlbi.nih.gov/files/docs/guidelines/prctg d_c.pdf.

28. National Institute for Health and Care Excellence: Obesity: Identification, Assessment and Management of Overweight and Obesity in Children, Young People and Adults. London, NICE, 2014 (cited 2015 Nov 30). Available from: http://www.nice.org.uk/guidance/cg189.

29. Kushner RF. Clinical Assessment and Management of Adult Obesity. Circulation. 2012;126:2870-77.

30. Ogden J, Stavinaki M, Stubbs J. Understanding the Role of Life Events in Weight Loss and Weight Gain. Psychol Health Med. 2009;14:239-49.

31. Whitaker RC, Wright JA, Pepe MS, Seidel KD, Dietz WH. Predicting Obesity in Young Adulthood from Childhood and Parental Obesity. N Engl J Med. 1997;337:869-73.

32. The NS, Suchindran C, North KE, Popkin BM, Gordon-Larsen P. Association of Adolescent Obesity with Risk of Severe Obesity in Adulthood. JAMA. 2010;304:2042-47.

33. Luppino FS, De Wit LM, Bouvy PF, Stijnen T, Cuijpers P, Penninx BW, et al. Overweight, Obesity, and Depression. Arch Gen Psychiatry. 2010;67:220-29.

34. Rollnick S, Butler CC, Kinnersley P, Gregory J, Mash B. Motivational Interviewing. BMJ 2010;340:1242-45.

35. WHO Expert Consultation. Appropriate Body-Mass Index for Asian Populations and Its Implications for Policy and Intervention Strategies. Lancet. 2004;363:157-63.

36. Yumuk V, Tsigos C, Fried M, Schindler K, Busetto L, Micic D, et al. European Guidelines for Obesity Management in Adults. Obes Facts. 2015;8:402-24.

37. National Heart, Lung, and Blood Institute. Clinical Guidelines on the Identification, Evaluation, and Treatment of Overweight and Obesity in Adults. Obes Res. 1998;6:S51-210.

38. Wadden TA, Webb VL, Moran CH, Bailer BA. Lifestyle Modification for Obesity: New 
Developments in Diet, Physical Activity, and Behavior Therapy. Circulation. 2012;125:1157-70.

39. Lowe MR. Self-Regulation of Energy Intake in the Prevention and Treatment of Obesity: Is It Feasible? Obes Res. 2003;11:S44-59.

40. US Department of Agriculture and US Department of Health and Human Services. Dietary Guidelines for Americans 2010. 7th ed. Washington, DC: US Government Printing Office; 2010.

41. Jakicic JM. The Effect of Physical Activity on Body Weight. Obesity. 2009;17:S34-38.

42. Donnelly JE, Blair SN, Jakicic JM, Manore MM, Rankin JW, Smith BK; American College of Sports Medicine. American College of Sports Medicine Position Stand: Appropriate Physical Activity Intervention Strategies for Weight Loss and Prevention of Weight Regain for Adults. Med Sci Sports Exerc. 2009;41:459-71.

43. Sacks FM, Bray GA, Carey VJ, Smith SR, Ryan DH, Anton SD, et al. Comparison of Weight-Loss Diets with Different Compositions of Fat, Protein, and Carbohydrates. N Engl J Med. 2009;360:859-73.

44. Sacks FM, Svetkey LP, Vollmr WM, Appel LJ, Bray GA, Harsha D, et al. Effects on Blood Pressure of Reduced Dietary Sodium and the Dietary Approaches to Stop Hypertension (DASH) Diet. N Engl J Med. 2001;344:3-10.

45. Position of the American Dietetic Association: Weight Management. J Am Diet Assoc. 2009;109:330-46.

46. Bodenheimer T, Lorig K, Holman H, Grumbach K. Patient Self Management of Chronic Disease in Primary Care. JAMA. 2002;288:2469-75.

47. Keogh JB, Clifton PM. The Role of Meal Replacements in Obesity Treatment. Obes Rev. 2005;6:229-34.

48. Wadden TA, West DS, Neiberg R, Wing RR, Ryan $\mathrm{DH}$, Johnson KC, et al. One-Year Weight Losses in the Look AHEAD Study: Factors Associated with Success. Obesity. 2009;17:713-22.

49. Hainer V, Toplak H, Mitrakou A. Treatment Modalities of Obesity: What Fits Whom? Diabetes Care. 2008;31(suppl 2):S269-77.
50. Dansinger ML, Tatsioni A, Wong JB, Chung M, Balk EM. Meta-Analysis: The Effect of Dietary Counseling for Weight Loss. Ann Intern Med. 2007;147:41-50.

51. Astrup A, Grunwald GK, Melanson EL, Saris WH, Hill JO. The Role of Low-Fat Diets in Body Weight Control: A Meta-Analysis of Ad Libitum Dietary Intervention Studies. Int J Obes Relat Metab Disord. 2000;24:1545-52.

52. Pirozzo S, Summerbell C, Cameron C, Glasziou P. Advice on Low-Fat Diets for Obesity. Cochrane Database Syst Rev. 2002;2:CD003640.

53. Fujioka K, Seaton TB, Rowe E, Jelinek CA, Raskin P, Lebovitz HE, et al. Weight Loss with Sibutramine Improves Glycaemic Control and Other Metabolic Parameters in Obese Patients with Type 2 Diabetes Mellitus. Diabetes Obes Metab. 2000;2:175-87.

54. Garrow JS, Summerbell CD. Meta-Analysis. Effect of exercise, with or without Dieting, on the Body Composition of Overweight Subjects. Eur J Clin Nutr. 1995;49:1-10.

55. Klem ML, Wing RR, McGuire MT, Seagle HM, Hill JO. A Descriptive Study of Individuals Successful at Long-Term Maintenance of Substantial Weight Loss. Am J Clin Nutr. 1997;66:239-46.

56. Yumuk V, Frühbeck G, Oppert JM, Woodward E, Toplak H. An EASO Position Statement on Multidisciplinary Obesity Management in Adults. Obes Facts. 2014;7:96-101.

57. Slentz CA, Duscha BD, Johnson JL, Ketchum K, Aiken LB, Samsa GP, et al. Effects of the Amount of Exercise on Body Weight, Body Composition, and Measures of Central Obesity. Arch Intern Med. 2004;164:31-39.

58. Pietrobelli A, Heymsfield SB. Establishing Body Composition in Obesity. $\mathrm{J}$ Endocrinol Invest. 2002;25:884-92.

59. Knowler WC, Barrett-Connor E, Fowler SE, Hamman RF, Lachin JM, Walker EA, et al. Diabetes Prevention Program Research Group. Reduction in the Incidence of Type 2 Diabetes with Lifestyle Intervention or Metformin. $\mathrm{N}$ Engl $\mathrm{J}$ Med. 2002;346:393-403. 
60. Blundell JE, Dulloo AG, Salvador J, Frühbeck G, on behalf of the EASO SAB Working Group on BMI: Beyond BMI - Phenotyping the Obesities. Obes Facts. 2014;7:322-28.

61. Schwarz PE, Lindström J, Kissimova-Scarbeck K, Szybinski Z, Barengo NC, Peltonen M, et al. The European Perspective of Type 2 Diabetes Prevention: Diabetes in Europe - Prevention Using Lifestyle, Physical Activity and Nutritional Intervention (DE-PLAN) Project. Exp Clin Endocrinol Diabetes. 2008;116:167-72.

62. Sampsel S, May J. Assessment and Management of Obesity and Comorbid Conditions. Dis Manag. 2007; 1:252-65.

63. Lahti-Koski M, Männistö S, Pietinen P, Vartiainen E. Prevalence of Weight Cycling and its Relation to Health Indicators in Finland. Obes Res. 2005;13:333-41.

64. Anderson JW, Konz EC, Frederich RC, Wood CL. Long-Term Weight-Loss Maintenance. Am J Clin Nutr. 2001;74:579-84.

65. Smith SR, Weissman NJ, Anderson CM, Sanchez M, Chuang E, Stubbe S, et al. Multicenter, Placebo-Controlled Trial of Lorcaserin for Weight Management. N Engl J Med. 2010;363:245-56.

66. Greenway FL, Fujioka K, Plodkowski RA, Mudaliar S, Guttadauria M, Erickson J, et al. Effect of Naltrexone plus Bupropion on Weight Loss in Overweight and Obese Adults (COR-1). Lancet. 2010;376:595-605.

67. Gadde KM, Allison DB, Ryan DH, Peterson CA, Troupin B, Schwiers ML, et al. Effects of Low-Dose, Controlled-Release, Phentermine plus Topiramate Combination on Weight and Associated Comorbidities in Overweight and Obese Adults (CONQUER). Lancet. 2011;377:1341-52.

68. Leslie WS, Hankey CR, Lean MEJ. Weight Gain As an Adverse Effect of Some Commonly Prescribed Drugs. Q J Med. 2007;100:395-404.

69. Luque CA, Rey JA. Sibutramine: A Serotonin-Norepinephrine Reuptake-Inhibitor for the Treatment of Obesity. Ann Pharmacother. 1999;33:968-78.
70. Toplak H, Woodward E, Yumuk V, Oppert JM, Halford JC, Frühbeck G. 2014 EASO Position Statement on the Use of Anti-Obesity Drugs. Obes Facts. 2015;8:166-74.

71. Pucci A, Finer N. New Medications for Treatment of Obesity: Metabolic and Cardiovascular Effects. Can J Cardiol. 2015;31:142-52.

72. Apovian CM, Aronne LJ, Bessesen DH, McDonnell ME, Murad MH, Pagotto U, et al. Pharmacological Management of Obesity: an Endocrine Society Clinical Practice Guideline. J Clin Endocrinol Metab. 2015;100:342-62.

73. Bray GA. Medical Treatment of Obesity: the Past, the Present and the Future. Best Pract Res Clin Gastroenterol. 2014;28:665-84.

74. Hill JO, Hauptman J, Anderson JW, Fujioka K, O'Neil PM, Smith DK, et al. Orlistat, a Lipase Inhibitor, for Weight Maintenance after Conventional Dieting: a 1-y Study. Am J Clin Nutr. 1999;69:1108-16.

75. Smith IG, Goulder MA, for the Subutramine Clinical Study 1047 Team. Randomized Placebo-Controlled Trial of Long-Term Treatment with Sibutramine in Mild to Moderate Obesity. J Fam Pract. 2001;50:505-12.

76. Apfelbaum $\mathrm{M}$, Vague $\mathrm{P}$, Ziegler $\mathrm{O}$, Hanotin $\mathrm{C}$, Thomas F, Leutenegger E. Long-Term Maintenance of Weight Loss after a Very-Low-Calorie Diet: a Randomized Blinded Trial of the Efficacy and Tolerability of Sibutramine. Am J Med. 1999;106:179-84.

77. Thomsen WJ, Grottick AJ, Menzaghi F, Reyes-Saldana H, Espitia S, Yuskin D, et al. A Novel Selective Human 5-Hydroxytryptamine 2C Agonist: in Vitro and in Vivo Pharmacological Characterization. J Pharmacol Exp Ther. 2008;325:577-87.

78. Chan EW, He Y, Chui CS, Wong AY, Lau WC, Wong IC. Efficacy and Safety of Lorcaserin in Obese Adults. Obes Rev. 2013;14:383-92.

79. Fujioka K. Safety and Tolerability of Medications Approved for Chronic Weight Management. Obesity (Silver Spring). 2015;23(suppl 1):S7-11. 
80. O’Neil PM, Smith SR, Weissman NJ, Fidler MC, Sanchez M, Zhang J, et al. Randomized Placebo Controlled Clinical Trial of Lorcaserin for Weight Loss in Type 2 Diabetes Mellitus. Obesity (Silver Spring). 2012;20:1426-36.

81. Fidler MC, Sanchez M, Raether B, Weissman NJ, Smith SR, Shanahan WR, et al. A One-Year Randomized Trial of Lorcaserin for Weight Loss in Obese and Overweight Adults. J Clin Endocrinol Metab. 2011;96:3067-77.

82. Weissman NJ, Sanchez M, Koch GG, Smith SR, Shanahan WR, Anderson CM. Echocardiographic Assessment of Cardiac Valvular Regurgitation with Lorcaserin. Circ Cardiovasc Imaging. 2013;6:560-67.

83. Singh J, Kumar R. Phentermine-Topiramate: First Combination Drug for Obesity. Int J Appl Basic Med Res. 2015;5:157-58.

84. Allison DB, Gadde KM, Garvey WT, Peterson CA, Schwiers ML, Najarian T, et al. Controlled-Release Phentermine/Topiramate in Severely Obese Adults: a Randomized Controlled Trial (EQUIP). Obesity (Silver Spring). 2012;20:330-42.

85. Garvey WT, Ryan DH, Look M, Gadde KM, Allison DB, Peterson CA, et al. Two-Year Sustained Weight Loss and Metabolic Benefits with Controlled-Release Phentermine/Topiramate in Obese and Overweight Adults (SEQUEL): a Randomized, Placebo-Controlled, Phase 3 Extension Study. Am J Clin Nutr. 2012;95:297-308.

86. Aronne LJ, Wadden TA, Peterson C, Winslow D, Odeh S, Gadde KM. Evaluation of Phentermine and Topiramate versus Phentermine/Topiramate Extended-Release in Obese Adults. Obesity (Silver Spring). 2013;21:2163-71.

87. Jordan J, Astrup A, Engeli S, Narkiewicz K, Day WW, Finer N. Cardiovascular Effects of Phentermine and Topiramate: a New Drug Combination for the Treatment of Obesity. J Hypertens. 2014;32:1178-88.

88. VIVUS Reports Topline Findings from FORTRESS [media release on the internet]. 2011December 21 (cited 2015 November 30). Available from: http://www.ir.vivus.com/releasedetail.cfm?ReleaseI $\mathrm{D}=634920$.
89. Fujioka K. Sustained-Release Naltrexone/ Bupropion: a Novel Pharmacologic Approach to Obesity and Food Craving. US Endocrinology. 2014;10:53-58.

90. Apovian CM, Aronne L, Rubino D, Still C, Wyatt H, Burns C, et al. A Randomized, Phase 3 Trial of Naltrexone SR/Bupropion SR on Weight and Obesity-Related Risk Factors (COR-II). Obesity (Silver Spring). 2013;21:935-43.

91. Wadden TA, Foreyt JP, Foster GD, Hill JO, Klein S, O'Neil PM, et al. Weight Loss with Naltrexone SR/Bupropion SR Combination Therapy as an Adjunct to Behavior Modification. Obesity (Silver Spring). 2011;19:110-20.

92. Hollander P, Gupta AK, Plodkowski R, Greenway F, Bays H, Burns C, et al. Effects of Naltrexone Sustained-Release/Bupropion Sustained-Release Combination Therapy on Body Weight and Glycemic Parameters in Overweight and Obese Patients with Type 2 Diabetes. Diabetes Care. 2013;36:4022-29.

93. Holst JJ. Incretin Hormones and The Satiation Signal. Int J Obes (Lond). 2013;37:1161-68.

94. Astrup A, Carraro R, Finer N, et al. Safety, Tolerability and Sustained Weight Loss Over 2 Years with the Once-Daily Human GLP-1 Analog, Liraglutide. Int J Obes (Lond). 2012;36:843-54.

95. Vilsboll T, Christensen M, Junker AE, Gluud LL. Effects of Glucagon-Like Peptide-1 Receptor Agonists on Weight Loss. BMJ. 2012;344:d7771.

96. Astrup A, Rossner S, Van Gaal L, Rissanen A, Niskanen L, Al Hakim M, et al. Effects of Liraglutide in the Treatment of Obesity. Lancet. 2009;374:1606-16.

97. Kim SH, Abbasi F, Lamendola C, Liu A, Ariel D, Schaaf P, et al. Benefits of Liraglutide Treatment in Overweight and Obese Older Individuals with Prediabetes. Diabetes Care. 2013;36:3276-82.

98. Wadden TA, Hollander P, Klein S, Niswender K, Woo V, Hale PM, et al. Weight Maintenance and Additional Weight Loss with Liraglutide after Low-Calorie-Diet-Induced Weight Loss. Int J Obes (Lond). 2013;37:1443-51. 
99. Pi-Sunyer X, Astrup A, Fujioka K, Greenway F, Halpern A, Krempf M, et al. A Randomized Controlled Trial of $3.0 \mathrm{mg}$ Liraglutide in Weight Management. N Engl J Med. 2015;373:11-22.

100. ClinicalTrials.gov [Internet]. Liraglutide Effect and Action in Diabetes: Evaluation of Cardiovascular Outcome Results - a Long Term Evaluation (cited 2015 November 30). Available from: https://www.clinicaltrials.gov/ct2/show/NCT011790 48.

101. Marso SP, Poulter NR, Nissen SE, Nauck MA, Zinman B, Daniels GH, et al. Design of the Liraglutide Effect and Action in Diabetes: Evaluation of Cardiovascular Outcome Results Trial. Am Heart J. 2013;166:823-30.

102. Daniels GH, Hegedüs L, Marso SP, Nauck MA, Zinman B, Bergenstal RM, et al. LEADER 2 Baseline Calcitonin in 9340 People with Type 2 Diabetes Enrolled in the Liraglutide Effect and Action in Diabetes: Evaluation of Cardiovascular Outcome Results (LEADER) Trial: Preliminary Observations. Diabetes Obes Metab. 2015;17:477-86.

103. Lean ME, Carraro R, Finer N, Hartvig H, Lindegaard ML, Rössner S, et al. Tolerability of Nausea and
Vomiting, and Associations with Weight Loss, in a Randomized Trial of Liraglutide in Obese, Non-Diabetic Adults. Int $\mathrm{J}$ Obes (Lond). 2013;38:689-97.

104. Gastrointestinal Surgery for Severe Obesity: National Institutes of Health Consensus Development Conference Statement. Am J Clin Nutr. 1992;55:S615-19.

105. Korner J, Inabnet W, Conwell IM, Taveras C, Daud A, Olivero-Rivera L, et al. Differential Effects of Gastric Bypass and Banding on Circulating Gut Hormone and Leptin Levels. Obesity. 2006;14:1553-61.

106. Miller K, Pump A, Hell E. Vertical Banded Gastroplasty versus Adjustable Gastric Banding: Prospective Long-Term Follow-Up Study. Surg Obes Relat Dis. 2007;3:84-90.

107. Mechanick JI, Kushner RF, Sugerman HJ. AACE/TOS/ASMBS Guidelines for Clinical Practice for the Perioperativenutritional, Metabolic, And Nonsurgical Support of the Bariatric Surgery Patient. Obesity. 2009;17(suppl):S1-70.

108. Sampsel S, May J. Assessment and Management of Obesity and Comorbid Conditions. Dis Manag. 2007;1:252-65. 